Article

\title{
Revisiting National Journalism Cultures in Post-Communist Countries: The Influence of Academic Scholarship
}

\author{
Halliki Harro-Loit \\ Institute of Social Studies, University of Tartu, 51003 Tartu, Estonia; E-Mail: halliki.harro@ut.ee \\ Submitted: 13 July 2015 | In Revised Form: 29 November 2015 | Accepted: 8 December 2015 | \\ Published: 29 December 2015
}

\begin{abstract}
The aim of this exploratory study is to develop the concept of the actor approach and journalism culture by adding a factor that has been more or less overlooked: academic scholarship. The paper also proposes to use the concept "discursive institutionalism" in order to clarify what knowledge and opinions about media are formed in the interaction of media institutions and academia with other institutions in society (e.g. educational, political and judicial). The concept "discursive institutionalism" includes the role of academia in providing new knowledge by conducting and disseminating research on the national and international levels, and this deserves greater attention. Although it is a common understanding that the role of academia is to prepare young professionals, it is less discussed how national media research and journalism education, in synergy, can create and maintain a collective understanding regarding the role and performance of national journalism in turbulent times. The paper is a meta-analysis of published research, and the empirical part of the study includes a close reading of academic articles, reports and conference presentations that are available in English about media in Central and Eastern European (CEE) countries. Examples of research from selected CEE countries provide a descriptive view of problems and tendencies concerning media performance in these countries. The proposed analytical approach aims to connect these problems and provide ideas for further research.
\end{abstract}

\section{Keywords}

academic scholarship; actor approach; CEE countries; discursive institutionalism, journalism culture

\section{Issue}

This article is part of the special issue "Turbulences of the Central and Eastern European Media", edited by Epp Lauk (University of Jyväskylä, Finland).

(C) 2015 by the author; licensee Cogitatio (Lisbon, Portugal). This article is licensed under a Creative Commons Attribution 4.0 International License (CC BY).

\section{Introduction}

Although millions of people constantly produce and disseminate information and news, democratic societies still need professional journalism to be a source of autonomous and reliable information, as well as analysis, and a potential watchdog over power-holders. Politicization (Dobek-Ostrowska, 2010), commercialization, instrumentalization and stagnation were extensively depicted in CEE countries in 2006-2008 and have been from 2011 onwards (Dobek-Ostrowska, 2013, p. 36). However, these problems are presented and interpreted quite differently in various CEE countries (e.g. Jakubowicz, 2001; Jakubowicz \& Sükösd, 2008; Lauk, 2009a). Dobek-Ostrowska proposes that CEE countries can be described as being on four levels of media professionalism and the implementation of media accountability instruments (MAI): "Estonia and the Czech Republic are leaders in the region; they have the best position in many rankings (including Democracy Index, Press Freedom Index). The second consists of Poland and Slovakia, which have eliminated many negative consequences of instrumentalization during recent years. Slovenia, Latvia and Lithuania share some troubles, where the media feel pressure from political actors. The worst situation of media accountability is traditionally observed in Bulgaria, Romania, and-from 2011-also in Hungary" (2013, p. 37). Why have media accountability and professionalism in CEE countries developed so differently? 
Various researchers have found that cultural factors play the most important role in daily media performance (e.g., Lauk, 2008, p. 209). At the same time, it seems to be characteristic of media scholars to not specify "cultural implications". Peter Gross, in his review (2013) of the book Central and Eastern European Media in Comparative Perspective: Politics, Economy and Culture, points out that although Colin Sparks gets everything right about the relationship between the media and elites, between the various elites, and the political and economic context that surrounds them, the explanatory essence of the cultural underpinning is insufficient.

This article is an exploratory study that aims to develop the concept of the actor approach and journalism culture by adding a factor that has been more or less overlooked: academic scholarship. In order to use this concept as an explanatory analytical model for cultural analysis, the article proposes that the concept of discursive institutionalism that makes it possible to combine the analysis of actors, the interaction between different actor groups and discourses that are produced by media and media scholars. As academic scholarship describes journalism culture from a scientific perspective, it has the potential to provide a diachronic self-description of the national journalism culture. Especially in transition societies, the ability to carry out analytical self-reflection (during rapid social changes) is a precondition for dealing with such problems as clientelism, politicization, political parallelism, commercialism and weak professionalism, as well as low levels of autonomy in journalism.

\section{Discursive Institutionalism and "Performative Discourse of Journalism"}

The concept of discursive institutionalism that the present article uses is connected with the interpretive or constructivist approach, initially introduced by Vivien Schmidt in 2002 and further developed in 2008. In this approach, "discourse" is the interactive process of conveying ideas, and therefore "discourses" influence cultural developments. Discursive institutionalism can be seen as having two forms: coordinative discourse among policy actors, and communicative discourse between political actors and the public (Schmidt, 2008). According to Schmidt, "discourse" is an important analytical tool for the study of the relations and interaction between ideas and institutions.

Therefore, in this study I use the concept "discursive institutionalism of journalism" in order to clarify what kinds of knowledge and opinions about media are formed in the interaction of media institutions and academia with other institutions in society (e.g. educational, political and judicial). The concept "discursive institutionalism" also includes the role of academia in providing new knowledge by conducting and dissemi- nating research on the national and international levels, preparing young professionals, constructing and maintaining collective memory regarding the role and performance of national journalism over time, and providing cultural sustainability and "bridges" during turbulent times.

The concept "performative discourse of journalism" (Broersma, 2010a, 2010b) is used to explain how journalistic discourse (as a specific discourse among other communicative discourses), or the "rules of the game" for media-workers and the public, are conveyed via textbooks, media classes, lawsuits etc. into daily reality. As Broersma (2010a, p. 30) has stated: "By making choices about the form and style of news, journalists affect how reality is experienced. If we want to understand media and the 'logic' of the public sphere, we have to examine the forms and styles of journalism that embody its performative power." The performative discourse of journalism is partly universal (form and style, conventions of genres, normative theories that impose certain role perceptions for journalists etc.), and therefore transmittable from country to country, being partly very contextual (i.e. the content of daily journalism). Broersma's approach to the performative discourse of journalism is critical, and he points out that to communication scholars and journalists this seems self-evident but to audiences it is not (Broersma 2010b, p. 22). As an example, he points out that while journalism's claim to truthfulness and reliability is crucial for existence and this is the basis of a shared social code between journalists and their public, in scholarship, after major cultural and linguistic changes, the idea that media provide a daily mirror is no longer generally accepted (Broersma, 2010a, p. 16).

Assuming that interaction between institutions for conveying ideas is crucial, one has to determine to what extent various actors share the knowledge of the performative discourse of media. In this paper, I argue that academic scholarship is a crucial factor in functional discursive institutionalism.

My basic argument for why academic discourse is an important element influencing journalism culture relies on what Peeter Torop, a professor of semiotics at the University of Tartu, has pointed out: selfdescription is a central characteristic of culture. Selfdescription is a process of auto-communication, and its result can be self-modelling, which determines the dominant factors, the principles of unification and the generative language of self-description (Torop, 2010).

In the context of the present study, the following notion from Torop is important: "Each attempt to describe culture from any scientific position proves, on a different level, to be a self-description of culture. By creating treatments of culture, we can also be part of culture's creativity" (Torop, 2005, pp. 169-170). For example, decades-long research traditions-carried out by both professional scholars and students who follow 
all the quality standards of academic researchprovide descriptions and analyses that make it possible to create the diachronic dimension of journalism culture, the ability to reflect upon changes in journalism culture over time. In addition, studies on media and journalism history can construct media as a hallmark in the collective memory of a nation and therefore be an important source of value communication concerning the media (King, 2008).

The concept of discursive institutionalism, combined with the actor approach, makes it possible to focus more directly on the question of how the different actors who create the media and communication culture obtain their knowledge, values, approaches and daily practices from the surrounding environment, and how they transmit these ideas back into daily practices.

\section{The Actor Approach as a Tool for Analysing Cultures}

The most elaborated concept concerning "cultural implications" (which have also been empirically tested in comparative studies) has been the concept of "journalism culture". Since 2001 various authors (e.g. Hollifield, Kosicki, \& Becker, 2001; Knott, Carrol, \& Meyer, 2002) have dealt with different aspects of journalism culture, e.g., "news culture", "newspaper cultures", "the culture of news production" and "editing culture" (Saks, 2011). Erdal (2009), for example, claims that complex media organizations contain a number of different journalistic sub-cultures, which include several production cultures. Hanitzsch (2006) introduced a taxonomy of journalism cultures, consisting of territorial, essentialist, value-centred, milieu-specific, organizational and professional journalism cultures. In conceptualizing journalism culture, Hanitzsch (2007) proposed constituents and principal dimensions of journalism culture that would work properly in diverse cultural contexts. Since then empirical cross-national studies have focused on journalists' perceptions of their professional values, roles and journalistic norms (Berganza-Conde, MMartín Oller-Alonso, \& Meier, 2010; Hanitzsch, 2011; Mellado, Moreira, Lagos, \& Hernandez, 2012; Reich \& Hanitzsch, 2013). Hence, the concept of journalism culture strongly addresses the actor approach, as well as the relationship between media and elites. This actorcentred approach means that personal and professional values (either consciously reflected or not) and actual performance of actors shape daily practices, and such practices in turn create discourses that both mould and reflect conventions within the media, as well as relations between the media and other institutions and groups in society (legislatures, courts, communities, etc.).

What seem to be more specific for CEE countries as transition societies are the rapid changes that have brought about the need to redefine professional values and conventions, and the fact that people might not be able to change so quickly (e.g. Coman, 2010; Krašovec \& Žagar, 2009; Salovaara, \& Juzefovics, 2012). Epp Lauk (2009a, p. 81), in analysing the performance of the professional community as one of the main influential factors in changing patterns of journalism in some of the CEE countries, concluded: "The process of the emergence of qualitatively new journalism cultures cannot be accomplished in just 20 years. It requires a complete generation shift in the media". Lauk does not elaborate on her idea of "generation shift", but in this article I will later provide conclusions from selected case studies (in the section on the interruption of journalism culture) that describe different problems connected to the "generation shift".

The Mediadem ${ }^{1}$ media policy analysis refers to the influence of the interaction between multiple actors: "Media policy, as expounded in a burgeoning literature on the subject, is shaped by a multiplicity of actors and institutional structures, besides the state, that interconnect and interact among each other in various venues and through various processes in order to organize the media system" (Anagnostou, Craufurd Smith, \& Psychogiopoulou, 2010, pp. 12-13).

A close reading of the studies of various scholars on media performance in CEE countries reveals that most of the problems are linked to political, business and media actors. For example, Henrik Örnebring points to "clientelism", which exists at the top level, mainly between politicians and media owners. More precisely, he claims that elite-to-elite communication is an important cultural factor that has received too little critical attention (Örnebring, 2012). Vaclav Štetka has carried out research on the relations between businessmen and journalists in the Czech Republic (Štetka, 2013), stressing that the economic recession and struggle for survival have made structural autonomy for big business a luxury commodity. Both authors implicitly claim that the reasons for political and economic instrumentalization lie in the values of elites. Io-

\footnotetext{
${ }^{1}$ MediaDem was a European research project which sought to understand and explain the factors that promoted or conversely prevented the development of policies supporting free and independent media. The project combined country-based studies in Belgium, Bulgaria, Croatia, Denmark, Estonia, Finland, Germany, Greece, Italy, Romania, Slovakia, Spain, Turkey and the UK with a comparative analysis across media sectors and various types of media services. It investigated the configuration of media policies in the aforementioned countries and examined the opportunities and challenges generated by new media services for media freedom and independence. Moreover, external pressures on the design and implementation of state media policies, stemming from the European Union and the Council of Europe, were thoroughly discussed and analysed. Project title: European Media Policies Revisited: Valuing and Reclaiming Free and Independent Media in Contemporary Democratic Systems. Project duration: April 2010-March 2013. Cf. http://www.mediadem.eliamep.gr
} 
na Coman and Peter Gross came to a similar conclusion while analysing the Romanian clientelism and political parallelism. They point out that the expression of the powers of manager journalists or star journalists (and not only of media owners and politicians) leads to clientelism and political parallelism in Romanian mass media (Coman \& Gross, 2012). Andrej Školkay, referring to several studies, points out that "although generalisations should be avoided, judicial decision-making in cases related to the freedom of speech, access to information and the protection of personal rights in the realm of the media has proved problematic for many lower courts" (Školkay, 2014, p. 118). Školkay refers to the inconsistencies that characterise domestic rulings and points out the problem of judges' low professional quality (Školkay, 2014, pp. 117, 118). "Some judges simply fear they would be criticised by the media or feel reluctant to decide fairly in cases involving politicians, public officials, including judges, or celebrities for fear of reprisals....Judges are not specialised, and thus have no in-depth knowledge to evaluate competing interests and rights in complicated cases related to the freedom of expression and the protection of one's honour or personality" (Školkay, 2014, 120). Školkay here points to one more "elite" actor group-judgesbut in the context of the present study his indication of cultural factors, such as the autonomy of the profession, and the lack of competencies in using argumentation that is based on Western traditions of freedom of speech and privacy, makes more sense.

In summary, it is not only the combination of media (accountability) system, media policy and/or economy that is different in CEE countries, but also the values and principles that people in different roles apply in their daily practices. The critical question is: would it be the academic scholarship that has enough autonomy and analytical capacity to bring the decision-making elite(s) under the pressure of value-clarification and accountability?

\section{Horizontal and Diachronic Ruptures of Journalism Culture}

Collapses and alterations of political regimes, wars, and societal and economic crises have significant impacts on the "life course" of journalism cultures in all European countries. As this study emphasises various actors, the notion of diachronic rupture is used to point out the perdition of the values, competencies and identities of the journalism community in the course of political and societal turmoil in CEE countries, especially in the 1990s. However, the concept of diachronic ruptures of journalism culture is not elaborated in the present article ${ }^{2}$, as the temporal dimension of different

2 The concept of ruptures in the development of journalism cultures is clarified in Lauk and Harro-Loit (forthcoming). ruptures goes beyond the transition time in the 1990s. For example, political and cultural ruptures may not be synchronous: while a change in a political regime leads to an instant rupture in the political culture, the journalistic discourse may have some ability to withstand political control (Harro-Loit, 2014, p. 268) and the academic discourse even more potential to maintain knowledge and values.

The notion of horizontal rupture between different actors helps to reveal the interruption in coordinative and communicative discourse between the professional media community, political and economic actors, media scholars and the public. In other words, the widely spread knowledge of the performative discourse of journalism in democratic society lessens the potential of horizontal rupture. In addition, if media researchers do not disseminate knowledge, or journalism students do not find jobs in journalism, there is a potential for horizontal rupture.

The researchers of CEE media and society have described the phenomena I here lable as the diachronic rupture of professional knowledge, values and identities, mainly in the 1990s. For example, researchers have pointed out that in the course of political and societal turmoil generations of journalists leave the profession or dramatically change their attitudes, but newcomers, although they are expected to be free from the historical-ideological burden, are not equipped with the performative discourse of journalism. Mihai Coman (2000, pp. 42-43) has written:

The birth of numerous new publications and radio and television stations brought about a rapid and uncontrolled increase in the number of those who work in the journalistic field. This does not necessarily mean that the number of professional journalists increased: only the number of those employed by enterprises which produce media goods increased. It was assumed that the newcomers, who were far more numerous than those with some experience in the communist press, would bring a new, non-ideologized approach, a greater social responsibility and more professionalism to the journalistic task.... The group is dominated numerically by young people who began working in the media after 1989. The majority do not have a relevant academic background or training. They present themselves as an antithesis to the old guard and consequently they promote: (a) an ideology of 'negation', (b) a sentiment of necessary superiority, based on the idea that those who have not work in the communist media were not touched by the communist ideology and (c) a certain professional selfsufficiency, based on the idea of a 'mission' in the name of which they have chosen the press, a mission which does not require any critical selfevaluation, or journalism education and training. 
Coman also refers to Peter Gross, who warned in 1996 that, while some progress has been made in professionalizing the field, to date the region's journalism is not of a calibre consonant with that of its Western neighbours (Gross, 1996. p. 94).

Stępińska and Ossowski (2012) recall that in the early 1990s in Poland about 1500 journalists left their jobs for various reasons, but even now three different generations have different role perceptions, depending on the time they entered the profession. Romania and Bulgaria have the same problem: experienced journalists have left the field (Ghinea \& Avădani, 2011; Smilova, Smilov, \& Ganev, 2011). Lucyna Szot, in analysing the main professional dilemmas of journalists in Poland (2013), argues that journalists as a group of actors are not in a strong position: "The very low activity of professional associations makes the situation worse. Journalists' organizations are too weak and divided. They are not able to articulate group interests or represent their profession effectively in Parliament....Polish journalists find it difficult to define their own identity" (Szot, 2013, pp. 231-232). Hadamik (2005) argues that the evolution of Polish journalism has had a strong literary, intellectual and political connotation, and those features have shaped the professional culture for many years, including during the communist era, when Polish journalists struggled with censorship for decades (Hadamik, 2005, pp. 214-215). The transition time of the 1990s produced a specific (different from the communist period) rupture in the journalism culture of CEE countries.

Jaromir Volek (2010, pp. 176-177) very explicitly points out the repetitive rupture in the professional culture during different periods of time in the Czech Republic:

Few occupations in the Czech Republic have changed their professional standards over the last 70 years as frequently as journalists.... Inevitably, the eras beginning in 1939, 1945, 1948 and 1968 always brought 'new', ideologically motivated redefinitions of the journalists' professional role.....Its latest transformation took place after the collapse of the old regime in 1989, when a dramatic institutional and professional change took place, starting with a serious disruption of the state monopoly over the media system.

Volek also reports that many journalists left the profession, others adapted to the new circumstances, many experienced journalists returned to the profession only after a 20-year involuntary break, and a new generation of novice journalists appeared. Volek describes the "proletarization of the journalists' community", especially on the local level.

At the beginning of the 1990s, in Estonia a lot of very young and inexperienced journalists were hired by media organizations (which thrived until the end of the 1990s) and a special expression was introduced for this time and generation: "juvenile-journalists" (Tali, 2010, pp. 55-56). The country report for the Mediadem project carried out by the Slovakian team reported: "The professionalism of journalists' output is also shaped by the sometimes limited competence of editors and many young journalists" (Školkay, Hong, \& Kutaš, 2011).

Inka Salovaara and Janis Juzefovics (2012, p. 770) have provided a description of how a change in owners caused processes that in this study I interpret as a rupture in ideology and professional values in a media organization: the Latvian newspaper Diena. Disloyal members of the staff were replaced by new and inexperienced reporters who were unable to produce analytical investigative materials, or ask critical, unpleasant questions.

Péter Bajomi-Lázár (2013, pp. 82-83) asks why political elites have attempted to exert pressure on the media, using the case of Hungary. He has provided a description of economic strategies (outsourcing) and a personnel policy that led to control of the content production processes:

The new regulation outsourced the production of the three public service broadcasters' news bulletins to MTI, and that of other programmes to the Media Fund. The number of each of the three public service broadcasters' employees has been reduced to a mere forty-nine people. Hence, neither the Directors General nor the Boards of Trustees (having some opposition nominees) of the public service broadcasters have much influence on production and programming. MTV has hired a number of pro-Fidesz journalists and activists, including....Philip Rákay former master of ceremony of Fidesz's street demonstrations, was appointed supervisor to the institution. The list of freshly appointed Fidesz loyalists could be long continued. Most of them receive wages of more than $1,000,000$ forints $(3,580$ euros) a month, while the average Hungarian earns 210,000 forints (750 euros).

Hence, while researchers admit that problems in media performance are linked to various political, business and media actors, they also describe phenomena that reflect diachronic and horizontal ruptures in the professional culture. It is obvious that post-communist countries need more changes than Western democratic countries. Still, as it appears form the above-cited authors', that the phenomena have neither supported the development of autonomous and professional journalism culture nor created preconditions for innovations.

\section{Academic Scholars and Scholarship in CEE Countries}

As Radu and Popa (2014) have found, there is a com- 
monly agreed understanding of the role and influence of journalism education on the profession, as well as on society: it forms journalists' attitudes, it is the usual entry route into newsrooms, it fosters media accountability regarding citizens and society, and it increases awareness of media accountability. Media education has been traditionally considered particularly important in the context of professionalization (e.g. Hoyer \& Lauk, 2003). As mentioned at the beginning of this study, I believe that media education should not be separated from research. I propose that journalism education and journalism research should be integrated into academic scholarship in journalism.

However, academic scholarship as a source and catalyst for necessary cultural changes has not received much analytical attention, except for a few programmes and projects (e.g. the Carnegie-Knight Initiative on the Future of Journalism Education, in 2005). The critical analytical questions include: are the media scholars in CEE countries able and motivated to act as engines of innovation and change? And are the different media-related actors and especially journalists ready and motivated to co-operate? The latter question is especially important, as the tension between the industry and academia has been a long-term problem in Europe, including CEE countries. For example, according to the survey carried out in Slovenia, the editors' very critical views of university journalism programmes are not based on actual knowledge of what the journalism faculties offer currently, but in some cases are based on what was happening a decade or more ago (Kovačič \& Laban, 2009). Köpplova and Jirák (2008, pp. 205-206) concluded from in-depth interviews with Czech journalists that there was a tend to underestimate journalistic university education, although the vision of a journalist as an educated person was alive in the Czech environment in 2002-2004 (when the survey was carried out).

The question of the potential of media scholars is also linked to the complicated notion of rupture and/or continuity in academia. In most cases, personnel policies in academia are less dependent on employers than they are in media organizations. Academic qualification requirements usually include international publishing, teaching evaluation, management skills etc., which are evaluated either internationally or by local experts in academia. In addition, the "career-building time" in academia is longer and professional values are less connected to the political system.

As mentioned above, academic discourse has more potential to withstand (at least to some extent) political pressure, and therefore, the diachronic continuity of journalism culture can be embedded in the academic discourse. Kovačič and Laban (2009, p. 100) describe the development of Slovenian journalism education:

At its beginning in 1964, journalism was taught at a "political school"; this was a time when Slovenia was one of the six socialist republics in the common state of Yugoslavia, when journalists were supposed to be socio-political workers responsible to the state (i.e. to the communist party leaders).... However, even at the outset the journalism education programme tried to follow examples not only from faculties in socialist states but also from the democratic world, largely because of Professor France Vreg, the founder of the journalism studies programme in Slovenia....Among other activities, a special fund was set up in the Faculty's journalism department to invite guest lecturers from both the East and the West."

Quite the same can be said about Estonian journalism education. In 1954, the founder of journalism education in Estonia, Professor Juhan Peegel (1919-2007), started the programme as part of the Estonian language and literature faculty at the University of Tartu. Therefore, journalists were not trained as political workers, and the academic research traditions began in the 1950s. Estonian journalism education was research-based from the very beginning, although academic discourse on media and society in post-Soviet countries could develop internationally as part of social or political science only since the end of the 1980s and the beginning of the 1990s. However, national research and publications in the field of Estonian journalism history have supported national identity and pride since the late 1950s (Lauk, 2009b). Hence, in these two cases (Slovenia and Estonia), there was actually no diachronic rupture, nor was there a need for a rupture because of existing resistance.

Today, the analytical question is: did Slovenian and Estonian journalism scholars gain some advantage from continuity? The question certainly needs more detailed analysis, but one can find a possible approach to this question using the QS World University Rankings (academic reputation + employer reputation + citations per paper $+\mathrm{H}$-index Citations). In 2015, there are four universities in CEE countries ranking among the top 200 in the area of communication and media studies: the University of Tartu (Estonia) ranks between 101 and 150; the University of Ljubljana (Slovenia), the University of Bucharest (Romania) and the University of Zagreb (Croatia) between 151 and 200.

This ranking takes into consideration various factors: academic reputation (40\%), citations per faculty (20\%), student-to-faculty ratio (20\%), employer reputation $(10 \%)$, international faculty ratio $(5 \%)$ and international student ratio (5\%). It is worth further investigating the academic scholars, traditions and scholarship at these universities.

Coming back to the question of the actual power of academia to catalyse changes and innovations, it is important to ask how to investigate the potential of 
scholarship on journalism in a CEE country. One possibility is to analyse the community of scholars. Claudia Mellado (2011) has conducted a survey of the professional patterns, scholarly productivity and educational characteristics of Chilean Journalism and Mass Communication (JMC) educators. She concludes: "Considering these factors, Chilean journalism education would be largely contributing to the professionalization of the practical activity of teaching journalism, but not to the development of new knowledge from the universityscholarly tradition." One important aspect Mellado points out is the need for implementation of minimum quality standards by universities (2011, p. 389).

One of the main quality standards in academia is international visibility and international networking. Articles published in acknowledged journals form a criterion for evaluation of research quality. International interaction also opens up the national "pool" and brings fresh ideas to local journalism culture. In addition, articles in international journals disseminate knowledge of a country.

Research should be useful to media and should be accessible to the professional community in national languages. This multidimensional activity requires a critical mass of media scholars and an expedient motivation system. As Balčytienè (2008, p. 222) points out:

One way to promote debate on media matters is by popularising results of academic research. In this respect, the situation seems to be the most auspicious in Estonia (compared to the other Baltic States-remark by the author), with the highest number of journalism and communication academics. Until now, the higher education reform in the Baltic countries and the system ranking of academic publications did not motivate scholars to write in their national languages, and thus, to increase popular public discussion on media matters and to widen knowledge and understanding of critical media concepts.

A strong research community usually supports better education (Nelles, 2001). Not only because of international "quality control" but also because the funding that comes both from scientific research and educational funds can often be used in synergy (Harro-Loit, 2009).

Many researchers have come to the conclusion that CEE countries have varied problems concerning the development of media-related scholarship. Mihai Coman has claimed (2000, p. 35):

First, the media system's evolution has been so rapid and, often, so unexpected, that findings are quickly overtaken by events: too often, after just a few months, an analysis becomes 'history'.... Research on media development in transitional societies can be difficult to obtain or, sometimes, inadequate for definitive analysis. Studies based on field research are published in the languages of the countries where the research was conducted and are usually inaccessible to foreign researchers.

In 2015, at the final plenary session of the $8^{\text {th }}$ Central and Eastern European Media and Communication Conference (CEECOM), Zrinjka Peruško, based on her research on the content of the national academic journals of CEE countries (journals published in 20132014), stated that "after 25 years of its institutionalization in university programs, journals and professional associations, we still have no comprehensive idea of the character of the discipline of communication and media studies in CEE today" (Peruško, 2015). At the same conference, Vaclav Štétka reached the same conclusion about media and communication studies: the research in CEE countries is not equal in quality to the research in Western countries. Štetka, in presenting a pilot study of the publication output of CEE-based authors in communication journals indexed in the Web of Science over the last decade, pointed out that one reason might be the research funding policies in CEE countries, which lead to poor results. He therefore comes to the same conclusion as Tarasheva (2011) regarding the place of Eastern European researchers in the international linguistics discourse: researchers from the former Eastern bloc do not publish as often as their colleagues from the West.

Hence, the problem is that some CEE countries fall into a vicious circle: low quality decreases competitive potential, and if journalism and media scholars are unable to compete internationally (in media and communication studies) and nationally (with other research fields), decreasing funding leads to an inability to attract strong researchers and educators. In addition, as Koivisto and Thomas (2008, p. 171) conclude in their comparative analysis on media and communication research in 9 countries all over the world, research, teaching and administrative tasks should be carried out synchronously in the situation of tough competition:

In terms of public funding, communication and media research projects are confronted by fierce competition for a share of an increasingly smaller pie.... Research is often done in 'spare time', after university academics have fulfilled an already demanding teaching and administrative burden, with obvious negative impacts upon the quality of the research. Insofar as the academic research units are usually the sites of education even-and especially-of future researchers for private enterprises, this lack of funding impacts not only upon the academic environment but also upon the quality of work done across the whole spectrum. 
In addition, the financing can come from research contracts with public and private organizations. But all these funding sources demand already existing strong researcher communities. In summary, growing competition in social sciences leads to a situation where the journalism education and research centres that developed sufficiently in the 1990s and have enough qualified scholars, have better chances to survive today.

\section{Conclusions}

The actor approach, combined with the concept of discursive institutionalism, makes it possible to integrate the actors, the discourses they produce and their interaction. Strong discursive institutionalism makes it possible to evaluate the reflexivity of media performance; hence, media governance may become less vulnerable to the egoistic and controversial interests of various stakeholders. On the contrary, ruptures (e.g. diachronic ruptures of journalists' knowledge and values as well as horizontal ruptures between different groups of actors) diminish the dialogue between different actors, their ability to understand each other and their mutual ability to demand practices from each other that support the values of democracy.

Horizontal rupture between different actors in society seems to be a common problem in transition societies: divisions between media educators and researchers, tension between media elite and rank-andfile journalists, distance between professional journalists and citizens, insufficient dialogue between national and international scholars etc. As the media culture is now global, missing or weak links between national and international discussions of media can also be seen as a rupture. Since the actual internationalization in media and communication studies in CEE countries started only in the 1990s, the research communities had to "run fast and far" within a decade. Determining whether this has influenced innovation in national journalism cultures or whether it has caused another horizontal rupture requires more analysis.

CEE countries also face a problem in diachronic cultural rupture, not only concerning the communism era, but even more connected with the1990s: the shift in generations of media professionals and traditions. The present study suggests that academic scholarship has the potential to withstand political pressure, as well as the power to repair temporal interruptions by providing retrospective self-descriptions, therefore supporting the process of auto-communication in journalism culture.

Finally, I argue that the concept of discursive institutionalism of journalism, combined with the actor approach and notions of various ruptures, has the potential to clarify the complexity of journalism culture and its ties to both unique national and more universal professional cultures.

\section{Acknowledgements}

This work was supported by institutional research funding IUT (20-38) of the Estonian Ministry of Education and Research, and Tartu University Centre of Excellence in Cultural Theory

\section{Conflict of Interests}

The author declares no conflict of interests.

\section{References}

Anagnostou, D., Craufurd Smith, R., \& Psychogiopoulou, E. (2010). The formation and implementation of national media policies in Europe and their relationship to democratic society and media freedom and independence: A theoretical and analytical frame for the MEDIADEM project. Athens: Eliamep. Retrieved from http://www.mediadem.eliamep.gr/wp-content/uplo ads/2010/05/theoretical-report.pdf

Bajomi-Lázár, P. (2013). The party colonisation of the media: The case of Hungary. East European Politics \& Societies, 27(1), 69-89.

Balčytienè, A. (2008). Changing journalistic discourses in the Baltic states-How to deal with cheap journalism. In K. Jakubowicz \& M. Sükösd (Eds.), Finding the right place on the map: Central and Eastern European media change in global perspective (pp. 211-226). Bristol \& Chicago: Intellect.

Berganza-Conde, M. R., Martín Oller-Alonso, M., \& Meier, K. (2010). Journalistic roles and objectivity in Spanish and Swiss journalism. An applied model of analysis of journalism culture. Revista Latina de Comunicación Social, 65, 488-502.

Broersma, M. (2010a). Journalism as performative discourse. The importance of form and style in journalism. In V. Rupar (Ed.), Journalism and meaningmaking: Reading the newspaper (pp 25-35). Cresskill, $\mathrm{NJ}$ : Hampton Press.

Broersma, M. (2010b). The unbearable limitations of journalism. On press critique and journalism's claim to truth. The International Communication Gazette, 72(1), 21-33.

Coman, M. (2000). Developments in journalism theory about media "transition" in Central and Eastern Europe 1990-99. Journalism Studies, 1(1), 35-56.

Coman, M. (2010). Journalistic Elites in post-communist Romania: From heroes of the revolution to media moguls. Journalism Studies, 11(4), 587-595.

Coman, l., \& Gross, P. (2012). Uncommonly common or truly exceptional? An alternative to the political system-based explanation of the Romanian mass media. International Journal of Press/Politics, 17(4), 457-479.

Dobek-Ostrowska, B. (2010). Party system and media in Poland-Dependencies and relations. Studia Medioznawcze, 2(41), 1-15. 
Dobek-Ostrowska, B. (2013). Media landscapes in transition: Focus on Central and Eastern Europe. In T. Eberwein \& L. Schneider-Mombaur (Eds.), MediaAct final research reports (pp 36-37). Dortmund: Technische Universität Dortmund. Retrieved from http://www.yumpu.com/document/view/15922335 /mediaact

Erdal, I. J. (2009) Cross-media (re)production cultures. The Journal of research into New Media Technologies, 15(2), 215-231.

Ghinea, C., \& Avădani, A. (2011). Does media policy promote media freedom and independence? The case of Slovakia. The MEDIADEM Report. Athens: Eliamep. Retrieved from http://www.mediadem.elia mep.gr/wp-content/uploads/2012/01/Romania.pdf

Gross, P. (1996). Mass media in revolution and national development: The Romanian laboratory. Ames: lowa State University Press.

Gross, P. (2013). Central and Eastern European media in comparative perspective: Politics, economy and culture. Slavic Review, 72(2), 402-404.

Hadamik, K. (2005). Between East and West or simply "made in Poland"? The many different styles of today's Polish journalism. In S. Hoyer \& H. Pöttker (Eds.), Diffusion of the news Paradigm 1850-2000 (pp 211-224). Göteborg: Nordicom.

Hanitzsch, T. (2006). Mapping journalism culture: A theoretical taxonomy and case studies from Indonesia. Asian Journal of Communication, 16(2), 169-186.

Hanitzsch, T. (2007). Deconstructing journalism culture: Toward a universal theory. Communication Theory, 17(4), 367-385.

Hanitzsch, T. (2011). Populist disseminators, detached watchdogs, critical change agents and opportunist facilitators: Professional milieus, the journalistic field and autonomy in 18 countries. International Communication Gazette, 73(6), 477-494.

Harro-Loit, H. (2009). Cost effectiveness of journalism education in a small nation state. Journalism Research, 2, 138-155.

Harro-Loit, H. (2014). The diachronic approach to journalism culture. In V. Lang \& K. Kull (Eds.). Estonian approaches to culture theory (pp. 262-280). Tartu: University of Tartu Press.

Hollifield, A. C., Kosicki, G. M., \& Becker, L. B. (2001). Organizational versus professional culture in the newsroom: Television news directors' and newspaper editors' hiring decisions. Journal of Broadcasting \& Electronic Media, 45(1), 92-117.

Hoyer, S., \& Lauk, E. (2003). The paradoxes of the journalistic profession: An historical perspective. Nordicom Review, 24(2), 3-18.

Jakubowicz, K. (2001). Rude awakening: Social and media change in Central and Eastern Europe. Javnost/The Public, 8(4), 59-80.

Jakubowicz, K., \& Sükösd, M. (2008). Twelve concepts regarding media system evolution and democratiza- tion in post-communist societies. In K. Jakubowicz \& M. Sükösd (Eds.), Finding the right place on the map: Central and Eastern European media change in global perspective (pp. 9-40). Bristol \& Chicago: Intellect.

King, E. (2008). The role of journalism history, and the academy, in the development of core knowledge in journalism education. Journalism \& Mass Communication Educator, 63(2), 166-178.

Knott, D. L., Carroll, V., \& Meyer, P. (2002). Social responsibility wins when CEO has been editor. Newspaper Research Journal, 23(1), 25-37.

Koivisto, J., \& Thomas, P. D. (2008). Mapping communication and media research: Paradigms, institutions, challenges. In Communication research center, department of communication, research reports 11 . Helsinki: Helsingin Sanomat Foundation, University of Helsinki.

Köpplova, B., \& Jirák, J. (2008) Brave new journalism: The attitudes of Czech journalists towards their own profession. In B. Dobek-Ostrowska \& M. Glowacki (Eds.), Comparing media systems in Central Europe. Between commercialization and politization (pp 197 206). Wroclaw: Wydawnictwo Uniwersytetu Wroclawskiego

Kovačič, M. P., \& Laban, V. (2009). Journalism education in Slovenia. Editors' views on the stereotyping of journalism graduates as incompetent theorists and socio-political workers. Journalism Practice, 3(1), 92107.

Krašovec, P., \& Žagar, Ž. (2009) Divisions and struggles of the Slovenian journalistic guild. A case study of contemporary European journalism. Journalism Studies, 10(1), 85-99.

Lauk, E. (2008). How will it all unfold? Media systems and journalism cultures in post-Communist countries. In K. Jakubowicz \& M. Sükösd (Eds.), Finding the right place on the map: Central and Eastern European media change in global perspective (pp. 192-212). Bristol \& Chicago: Intellect.

Lauk, E. (2009a). Changing patterns of journalism in the new EU Countries. Journalism Studies, 10(1), 69-84.

Lauk, E. (2009b). The Estonian journalism education landscape. In G. Terzis (Ed.), European journalism education (pp. 393-408). Bristol \& Chicago: Intellect.

Lauk, E., \& Harro-Loit, H. (Forthcoming). Journalistic autonomy as a professional value. In Journalism culture: The European perspective.

Mellado, C. (2011). Examining professional and academic culture in Chilean journalism and mass communication education. Journalism Studies, 12(3), 375-391.

Mellado, C., Moreira, S. V., Lagos, C., \& Hernandez M. E. (2012). Comparing journalism cultures in Latin America: The case of Chile, Brazil and Mexico. The International Communication Gazette, 74(1), 60-77.

Nelles, W. (2001) Toward better communications cooperation for Central and South Eastern Europe: Trends and prospects. Higher Education in Europe, 
26(2), 227-239.

Örnebring, H. (2012). Clientelism, elites, and the media in Central and Eastern Europe. International Journal of Press/Politics, 17(4), 497-515.

Peruško, Z. (2015). Past and present of communication and media studies in CEE. A speech on the plenary session 4 at the 8th Central and Eastern European Media and Communication Conference (CEECOM) in Zagreb, 14 June.

Radu, R.-N., \& Popa, D.-A. (2014). Media accountability and journalism education. In S. Fengler, T. Eberwein, G. Mazzoleni, C. Porlezza, \& S. Russ-Mohl (Eds.), Journalists and media accountability. An international study of news people in the digital age (pp 249263). New York: Peter Lang Publishing.

Reich, Z., \& Hanitzsch, T. (2013). Determinants of journalists' professional autonomy: Individual and national level factors matter more than organizational ones. Mass Communication \& Society, 16(1), 133156.

Saks, K. (2011). The formation of editing culture and practice in Estonian newspapers 1988-2005 (Dissertationes de mediis et communicationibus Universitatis Tartuensis). Tartu: University of Tartu.

Salovaara, I. \& Juzefovics, J. (2012). Who pays for good journalism? Journalism Studies. 13(5/6), 763-774.

Schmidt, V. A. (2008). Discursive institutionalism: The explanatory power of ideas and discourse. Annual Review of Political Science, 11(1), 303-326.

Školkay, A. (2014). The freedom of expression in the media and the Slovak judiciary. In E. Psychogiopoulou (Ed.). Media policies revisited. The challenge for media freedom and independence ( $\mathrm{pp}$ 115-128). Hampshire: Palgrave Macmillan.

Školkay, A., Hong, M., \& Kutaš, R. (2011). Does media policy promote media freedom and independence? The case of Slovakia. The MEDIADEM Report. Athens: Eliamep. Retrieved from http://www.mediadem.eli amep.gr/wp-content/uploads/2012/01/Slovakia.pdf

Smilova, R., Smilov, D., \& Georgy Ganev, G. (2011). Does media policy promote media freedom and independence? The case of Bulgaria. The MEDIADEM Report. Athens: Eliamep. Retrieved from http://www.media dem.eliamep.gr/wp-content/uploads/2012/01/

Bulgaria.pdf

Stępińska, A., \& Ossowski, S. (2012). Dziennikarze w Polsce: wartości, priorytety i standardy zawodowe [Journalists in Poland: Values, priorities and professional standards]. Studia Medioznawcze, 1(48), 1-15. Retrieved from http://sm.id.uw.edu.pl/Numery/ 2011_1_44/stepinska-en.pdf

Štetka, V. (2013). From multinationals to business tycoons: Media ownership and journalistic autonomy in Central and Eastern Europe. International Journal of Press/Politics, 17(4), 433-456.

Szot, L. (2013). Main professional dilemmas of journalists in Poland. In B. Dobek-Ostrowska, M. Głowacki, K, Jakubowicz, \& M. Sükösd (Eds.), Comparative media systems. European and global perspectives (pp. 209-232). Budapest \& New York: Central European University Press.

Tali, P. (2010). Eesti ajakirjanike töö iseloomu muutumine 1988-2009 [Changes in the work of Estonian journalists in 1988-2009]. MA thesis. Tartu: Institute of Journalism and communication, University of Tartu. Retrieved from http://dspace.ut.ee/handle/ 10062/15273

Tarasheva, E. (2011). Critical discourse analysis applied to corpora from specialized journals. The place of Eastern European researchers in international discourse. Discourse Society, 22(2), 190-208.

Torop, P. (2005). Semiosphere and/as the research object of semiotics of culture. Sign Systems Studies, 33(1), 159-173.

Torop, P. (2010). Translation as communication and auto-communication. Applied Semiotics/Sémiotique appliquée, 9(24), 3-10. Retrieved from http://french. chass.utoronto.ca/as-sa/ASSA-No24/Article1en.html

Volek, J. (2010). Czech journalists after the collapse of the old media system: Looking for a new professional self-image. In B. Dobek-Ostrowska, M. Głowacki, K, Jakubowicz, \& M. Sükösd (Eds.), Comparative media systems. European and global perspectives (pp 171194). Budapest: Central European University.

\section{About the Author}

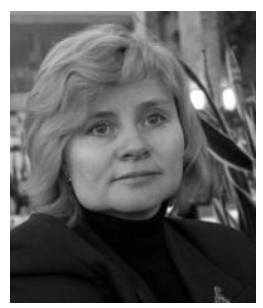

Dr. Halliki Harro-Loit

Halliki Harro-Loit is currently professor of journalism at the University of Tartu and is heading the Institute of Social Studies. Her research interests include journalism studies, media ethics and law, comparative journalism and communication studies. She has edited and contributed to the book The Curving Mirror of Time (2013) which represents her new interest in social time and diachronic dimension of journalism culture. 